\title{
Empirical Models to Quantify the Nutritive Characteristics of Annual Pastures in
}

\section{South-West Western Australia}

\author{
A.G.T. Schut ${ }^{1,2}$, S.G. Gherardi ${ }^{3}$ and D.A. Wood $^{3}$
}

${ }^{1}$ Department of Spatial Sciences, Curtin University of Technology, GPO Box U1987, Perth, W.A.

${ }^{2}$ Cooperative Research Centre for Spatial Information, 723 Swanston street, Parkville 3052, Victoria

${ }^{3}$ Department of Agriculture and Food Western Australia, Locked Bag 4, Bentley Delivery Centre 6983, W.A.

\section{Acknowledgements}

We thank the CRC for Spatial Information for funding this work. We acknowledge the in-kind support of CSBP Limited (WA) for soil analysis and fertilizer supply recommendations, CSIRO Livestock Industries for their in-kind support in analyzing pasture samples and the Department of Agriculture and Food Western Australia for providing trial sites, technical- and financial support. We thank Mrs Elizabeth Hulm for her expertise and work in laboratory analysis and Dr Jane Speijers for her valuable advice on statistical analysis and two anonymous reviewers for their valuable comments and suggestions. 


\section{Abstract}

The objective of this paper is to quantify the magnitude of the major sources of variation which affect in-vitro digestibility (DMD) and concentrations of neutral detergent fiber (NDF), acid detergent fiber (ADF) and crude protein (CP) of annual pastures in Mediterranean climate zones. Four experiments were conducted in the south-west of Western Australia in 2006/07 and 2007/08 where the supply of nitrogen, phosphorous, potassium or sulphur and pasture types was varied. Effects of seasonality, fertilizer application, pasture type and site were analyzed with an auto-regression maximum likelihood procedure. Temperature sum was used to explain the seasonal differences in DMD, CP, NDF and ADF. Seasonality explained 82, 79, 79, and $62 \%$ of the total variation in DMD, NDF, ADF and CP, respectively, with only an additional 5, 5, 6 and $24 \%$ being explained by the combined effects of site/management, fertilizer application and pasture type. The differences in DMD, NDF, ADF and CP, between sites were 2.3-6.0\%, 4.6-18.7\%, 5.8-8.6\% and 1.517.4\%, respectively. Pasture types differed by $6.6-9.5 \%, 9.0-11.4 \%, 3.1-6.1 \%, 5.1-5.2 \%$ for DMD, NDF, ADF and CP, respectively. The differences between sites and pasture types were markedly larger for CP, NDF and ADF than for DMD. Fertilizer application did not affect nutritive characteristics, with the exception of $\mathrm{N}$ application rates on $\mathrm{CP}$. It was concluded that the seasonality model captured nearly all of the temporal the availability of $\mathrm{N}$. 


\section{Introduction}

Optimising the conversion of available feed to saleable products (wool, milk or meat) is the key to profitable grazing. Setting stocking rate to annual pasture production and matching available feed to animal requirements are the key elements to ensure that this is achieved (Doyle et al. 1997). Optimizing grazing management requires knowledge about the amount and nutritive characteristics of the feed on offer. A good estimate of regional means for the most important nutritive characteristics for a region would, therefore, be a very useful as starting point. Comparisons of the nutritive value of feed on offer in paddocks with regional means also provides means to benchmark grazing management and pasture improvement and adjust rule-ofthumb recommendations for supplementary feeding.

Nutritive characteristics, the plant factors affecting the nutritive value, are governed by plant development, genotype, nutrient availability and grazing management. Annual pastures regenerate from seed and, therefore, go through their full life cycle from emergence and vegetative growth to flowering and senescence. The stage of development determines growth and decay of leaf, flower and stem material, components which have contrasting quality characteristics (Ru et al. 2000). Rates of development, and thus the duration of each development stage, are strongly linked to temperature and depend upon the genotype of the plant (Coleman et al. 2002). The in-vitro dry matter digestibility (DMD) and lignin content of grass is also directly reduced by high temperatures (Henry et al. 2000). Frequent defoliation may reduce plant development rates and increase the duration of the vegetative growth stage but once grazing pressure is reduced, the development rate increases and quality deteriorates quickly (Callow et al. 2000). However, Cayley et al. (2002) showed that the effect of moderate grazing pressure on DMD and crude protein (CP) was small and inconsistent for a range of plants at different growth stages. Ru and Fortune (2000; 2001) found that the DMD of subterranean clover genotypes grown in south-west WA differed by $7-20 \%$ in the growing season. McIvor and Smith (1973) found differences in DMD and CP between broadleaf species, grasses and clover. The differences in DMD ranged from 7-10\% and for CP from $6.3-11.3 \%$ in both winter (vegetative growth stage) and spring (generative growth stage). DMD and CP are also influenced by nutrient application rates, with increasing applications of nitrogen $(\mathrm{N})$ and phosphorous $(\mathrm{P})$ increasing $\mathrm{CP}$ and DMD values (Cayley et al. 2002). The nutritive characteristics and nutrient concentrations of plants are linked and correlated to each other due to growth and dry matter accumulation. $\mathrm{N}$ (and thus $\mathrm{CP}$ ) and other nutrient contents are strongly diluted with increasing plant yields (Justes et al. 1994; Lemaire et al. 1989). However, nutrient application may accelerate plant growth and dilution by structural carbohydrates, resulting in a 
significant decrease in concentrations of nutrients, protein and water soluble carbohydrates on a dry weight basis.

Cumulative daily mean temperatures above $4.5{ }^{\circ} \mathrm{C}$ (temperature sum or cumulative temperature) can be used to describe the temporal change in DMD and CP typical for pastures dominated by annual species in the Mediterranean climate zones of Australia (Schut et al. 2006a). The change in plant composition and nutritive characteristics driven by climatic factors is also referred to as seasonality. They found that the differences in DMD between pastures dominated by subterranean clover, annual ryegrass or broadleaf species (mainly capeweed) in Victoria and Western Australia were small, in contrast to the large differences in CP. They hypothesised that intensive grazing would extend the period of vegetative growth and delay the typical decline in DMD and CP values. However, they highlighted that little is known about the within and between paddock variation in DMD and CP. There is even less information available about the temporal and spatial (i.e. within and between) paddock variation in neutral detergent fiber (NDF) and acid detergent fiber (ADF) values, important indicators of feed intake (an increase in fiber content decreases feed intake) and energy content (an increase in ADF decreases available energy).

We hypothesize that the typical change of DMD (Schut et al. 2006a) and concentrations of NDF and ADF within a growing season is mainly governed by temperature and plant development stage and 1) can be quantified with temperature sum and 2) used to describe an average pasture and indicate the spatial variation to expect, in high and low quality pastures; 3) the relative level of DMD and concentrations of CP, NDF and ADF compared to this average pasture is determined by grazing pressure, nutrient application rates and the type of annual pasture, and that these are the major sources of variation within and between paddocks. So, knowledge about type of annual pasture, nutrient application rates and grazing management, can be used to characterise differences between pastures and to benchmark against the average pasture. The objective of this manuscript is to test this hypothesis and compare predictions of DMD and concentrations of CP, NDF and ADF based on cumulative temperature with experimental data collected from four experiments conducted in the south-west of Western Australia in 2006/07 and 2007/08. The effects of pasture type, nutrient application levels and site (including location and grazing management) on the nutritive characteristics of annual pastures were evaluated.

\section{Materials and methods}

Four experiments were conducted in the south-west of Western Australia to gather pasture samples.

All sites were located in the Mediterranean climatic zone with hot, dry summers and mild, wet winters. On 
average, the growing season starts after the arrival of the first rains in April-May. In these regions, pastures are dominated by annual species which senesce in late spring, normally between October and November.

\section{6/07 Experiments}

The first experiment was located at the Badgingarra Research Station in WA at $-30.34^{\circ}$ latitude and $115.54^{\circ}$ longitude in a 30 ha paddock. Badgingarra receives an average annual rainfall of about $560 \mathrm{~mm}$ and has on average a growing season of about 185 days. Analysis of soil samples (CSBP laboratories, Bibra Lake, WA) taken in the summer of 2005/06 revealed that the fertility status of carbon (C), P, potassium (K) and sulphur (S) of this paddock was low to marginal (1.0\% C, $9.9 \mathrm{mg}$ P, $62 \mathrm{mg} \mathrm{K}$, and $6.3 \mathrm{mg} \mathrm{S}$ per kg dry soil). During the experiment in 2006, hardly any legumes were present, probably due to the false break in April. Within this paddock, 18 plots were assigned to a Northern and a Southern block. The Northern block was dominated by Brome grass (Bromus diandrus) and Barley grass (Horleum leporium) (about $80 \%$ of plants present were grasses, and 20\% broadleaves), the Southern block by capeweed (Arctotheca calendula) and Barley grass (about 75\% broadleaves and 25\% of plants were grasses). Each plot was $55 \mathrm{~m}$ long by $55 \mathrm{~m}$ wide. Treatments consisted of various rates of urea $\left(0,20,40\right.$ and $\left.60 \mathrm{~N} \mathrm{~kg} \mathrm{ha}^{-1}\right)$, muriate of potassium $(0,17$ and $\left.34 \mathrm{~kg} \mathrm{~K} \mathrm{ha}^{-1}\right)$ or super-phosphate $\left(0,9.4\right.$ and $\left.18.7 \mathrm{~kg} \mathrm{P} \mathrm{ha}^{-1}\right)$. This resulted in 36 unique combinations of fertilizer inputs, one combination for each plot. Treatments were randomly assigned to plots within soil fertility classes (based on $\mathrm{P}$ and $\mathrm{K}$ levels) to assure that plots receiving low to moderate $\mathrm{P}$ and $\mathrm{K}$ applications were located on plots with a low P or K status. All fertilizers were applied in one application. Due to the extremely late first rains (end of June), the growing season started 6-8 weeks later than expected and the scheduled follow up application was cancelled. The paddock was grazed from late July to late November with wethers, at a stocking rate of $25 \mathrm{DSE} \mathrm{ha}^{-1}$, maintaining the pasture between 1,500-2,500 $\mathrm{kg}_{\mathrm{DM}} \mathrm{ha}^{-1}$ until mid spring.

The second experiment was located on the Vasse Research Station WA in a 24 ha paddock at $33.66^{\circ}$ latitude and $115.34^{\circ}$ longitude. Vasse receives an annual mean rainfall of about $790 \mathrm{~mm}$ and has a mean length of the growing season of about 215 days. Analysis of soil samples (CSBP laboratories, Bibra Lake, WA) taken in the summer of 2005/06 revealed that the fertility status of this paddock was high for P and S and low for K (26.8 mg P, $18.8 \mathrm{mg} \mathrm{S}$ and $17.3 \mathrm{mg} \mathrm{K}$ per kg of dry soil). Annual ryegrass (Lolium rigidum Gaud.) and capeweed were the dominant species with low amounts of subterraneum clover (Trifolium subterraneum), ranging from 0-10\% subterraneum clover, 25-80\% annual grasses and 15-70\% 
broadleaves. There were 36 plots within this paddock, each plot $60 \mathrm{~m}$ long by $60 \mathrm{~m}$ wide. Planned treatments consisted of various rates of urea $\left(0,45,90\right.$ and $\left.135 \mathrm{~N} \mathrm{~kg} \mathrm{ha}^{-1}\right)$, muriate of potassium $\left(0,50\right.$ and $100 \mathrm{~kg} \mathrm{~K} \mathrm{ha}^{-}$ ${ }^{1}$ ) or gypsum (0, 25 and $\left.50 \mathrm{~kg} \mathrm{~S} \mathrm{ha}^{-1}\right)$, resulting in 36 unique combinations of fertilizer input, one for each plot. S was chosen as a treatment because in previous years at Vasse, $\mathrm{S}$ was deficient in spring when high groundwater tables reach the surface and soil $\mathrm{S}$ becomes unavailable to plants. Under high $\mathrm{N}$ supply, $\mathrm{S}$ deficiency can limit yield and quality (crude protein content) of pastures (Gierus et al. 2005). For N and K, only 2 (of the 3 planned) split applications were administered due to the very late first rains on the $13^{\text {th }}$ of June, reducing the planned treatment rates by one-third. Gypsum (S) was all applied only once. At Vasse, large amounts of $\mathrm{S}$ are stored in the subsoil, however, this becomes inaccessible to plant roots when groundwater levels approach the surface. In 2006, groundwater levels didn’t reach the surface due to low winter rainfall and as a consequence it was expected that an ample supply of S was available to the plants. Therefore, no second and third applications of Gypsum were administered. The paddock was grazed with steers or heifers, aimed at maintaining the above ground biomass between 2,500 - 3,500 $\mathrm{kg} \mathrm{DM} \mathrm{ha}^{-1}$.

\section{7/08 Experiments}

Experiments conducted in 2007/08 were located at Vasse Research Station (see above) and Avondale Research Station in WA, at $-32.12^{\circ}$ latitude and $116.87^{\circ}$ longitude. Pasture species [Wimmera Ryegrass (Lolium rigidum Gaud., cv Wimmera, early flowering), Italian Ryegrass (Lolium multiflorum Lam., cv Rocket), Subterraneum clover (Trifolium subterraneum, cv Dalkeith), Biserrula (Biserrula pelecinus, cv. Casbah) or Balansa clover (Trifolium michelianum, cv. Paradana) and Serradella (Ornithopus spp., cv. Santorini)] were sown onto the plots. The legume seeds were inoculated with Alosca ${ }^{\circledR}$ prior to sowing. Both experiments were a randomized block design consisting of 36 plots $10 \mathrm{~m}$ wide by $20 \mathrm{~m}$ long with 3 blocks of 12 plots containing the replicates. $\mathrm{N}$ application rates $(0,35$ and $70 \mathrm{~kg} / \mathrm{ha})$ were varied on 4 sub-blocks, consisting of 3 plots, within the block for each replicate. Sub-blocks contained sown grasses and volunteer pasture (3 sub-blocks per block) or legumes and volunteer pasture (1 sub-block per block). $\mathrm{N}$ application rates were varied across sub-blocks, but no $\mathrm{N}$ was applied to the sub-block with legumes.

At Vasse, 3 weeks after the break-of-season (April), weeds were controlled with glyphosate prior to sowing. The plots were sown on 21 May with Wimmera Ryegrass, Italian Ryegrass, Subterranean clover, Balansa clover or Serradella. Following some light rains shortly after sowing, a long dry spell prevented plant emergence until the end of June. The sown legumes did not emerge and these plots were discarded from the 
experiment. Volunteer pasture plots were dominated by capeweed. N was applied on 35 and $70 \mathrm{~kg}$ N/ha subblocks on the 8 August and the 15 September. Plots were rotationally grazed with heifers.

At Avondale, the first winter rains (break of season) arrived on the 26 June 2007. Due to this late break, glyphosate was applied at sowing. Plots were sown with Wimmera Ryegrass, Italian Ryegrass, Subterranean clover, Biserrula and Serradella. Insects on the legumes were controlled with Fusilade. On 7 August and 13 September urea was applied on the 35 and $70 \mathrm{~kg} \mathrm{~N} / \mathrm{ha}$ sub-blocks. After the first samples were collected (31 August) a total of 270 weathers were used to graze the plots. Following this initial grazing, a rotational grazing regime was used to maintain the level of biomass at around $2000 \mathrm{~kg} \mathrm{DM} / \mathrm{ha}$. The volunteer pasture plots were dominated by Barley grass.

\section{Measurements}

For the experiments in 2006/07, the visual estimates of botanical composition were recorded in October 2006. The plots were subsequently categorized in two groups, either dominated by grasses or by broadleaf plant species. At Badgingarra, there were a total of 18 plots dominated by grasses and 18 by broadleaf species, whereas at Vasse 23 plots were dominated by grasses and 13 by broadleaf plants (mainly capeweed).

All field data on each plot were collected in a narrow transect about $1 \mathrm{~m}$ wide by $45-50 \mathrm{~m}$ (2006) or $20 \mathrm{~m}$ (2007) long. At each sampling event (sampling events can be derived from figures 1-3), this transect was moved to a new location within the plot to avoid re-sampling the same location. About every $5 \mathrm{~m}$ (2006) or $2 \mathrm{~m}$ (2007) along the length of each transect a visual estimate of the feed on offer (FOO, $\mathrm{kg} \mathrm{DM} / \mathrm{ha}$ ), including green and dead material, was recorded. These visual assessments undertaken by an experienced pasture technician were calibrated for each day of assessment by collecting plant material from about 15 samples covering the full range in FOO estimates in 15 quadrats $\left(0.1 \mathrm{~m}^{2}\right)$ cut to ground level using electric clippers. Samples collected from quadrats were rinsed in water to remove soil and dried at $60{ }^{\circ} \mathrm{C}$ to determine DM content. Reflectance spectra were recorded with a hand-held spectrometer (ASD FieldSpec Jr, ASD, Boulder, Colorado, USA) and were used to estimate the fraction of green and dead material. Abundance of green and dead material and soil was estimated with fully constrained linear spectral un-mixing procedures based on continuum removed spectra (see Heinz and Chang (2001) and references therein). Spectra were collected on the same transect as used for collection of samples at 5 m (2006/07) or 2 m (2007/08) sampling intervals. Afterwards, means for each plot were calculated. The amount of green FOO (gFOO) and dead FOO 
(dFOO) was derived from the total amount of visually assessed FOO and the spectral data collected. Pasture quality samples were collected by pooling material from cuts undertaken every $5 \mathrm{~m}$ (2006/07) or $2 \mathrm{~m}$ (2007/08) in a $1 \mathrm{~m}$ long and $5 \mathrm{~cm}$ wide strip cut at 4-5 cm above the soil surface. Pasture quality samples were refrigerated directly after cutting. Samples were dried in an oven at $60{ }^{\circ} \mathrm{C}$ for about 48 hours and dry matter concentrations (DMc) were determined gravimetrically by weighing. After grinding through a $1 \mathrm{~mm}$ screen, a sub-sample was analyzed with a NIR spectrometer (NIRSystems 6500, FOSS NIRSsystems Inc., Denmark) for estimating DMD, NDF and ADF concentrations. A total 169 samples (20\%) were analyzed with traditional wet chemistry to calibrate the NIRS equations, selected randomly or as extremes based on NIRS spectra. The DMD was adjusted for in-vivo digestibility using Australian Feed Industry Association and other feeding trial standards. The NDF and ADF concentrations were determined with an $\mathrm{ANKOM}^{200}$ (ANKOM Technology, New York, USA) fibre analyser including sodium sulphite for NDF analysis. Concentrations were expressed on a dry basis without corrections for ash content.

The standard errors of cross validation for NIRS were 2.8\%, 3.3\% and 2.7\% for DMD, NDF and ADF respectively for the NIRS equation used. All 865 samples were analyzed with NIRS (CSIRO, Floreat Park, WA) and inductively coupled plasma optical emission-spectrometry (CSBP laboratories, Bibra Lake, WA) to determine concentrations of $\mathrm{N}, \mathrm{P}, \mathrm{K}$ and $\mathrm{S}$. CP concentrations were calculated by multiplying $\mathrm{N}$ concentrations by 6.25 .

\section{Analysis of the effects of treatments on nutritive characteristics}

Treatment effects were evaluated by a restricted maximum likelihood (REML) procedure with a first order auto-regression to account for correlation between harvests (Payne et al. 2007). Two models were developed, one for the experiments in 2006/07 (Vasse and Badgingarra) where N, P or S and K fertilizer levels varied and one for the experiments in 2007/08 (Vasse and Avondale) where $\mathrm{N}$ and pasture type varied. In both cases, the random model included plots per experiment. The fixed model included harvest day number counted from 1 June onwards, experiment number, pasture type, first and second order of the treatment levels of N, P, S and K application and all interactions. For the model, including experimental data from 2006/07, application of P and S were set to 0 for Vasse and Badgingarra, respectively. The significance of the terms included in the model was evaluated with the F statistic based on the Chi-squared distribution. After a number of iterations, non-significant terms were removed until only significant terms with a $\mathrm{F}$ probability $<0.05$ remained. When only interactions were significant, main effects were not removed. 
It was important to account for the residual error, as it will contribute to the variation in any measurements taken. This error describes the variation between replicates when accounting for site, block and treatment effects (using REML) and may be due to measurement error and random variation. The random error was estimated for the experiments in 2007 at each harvest using a REML procedure with N, pasture type and the interaction modelled as fixed effect and plot number and block number modelled as random effect. The mean of these errors was calculated for each variable of interest. Genstat release 11 (VSN International) was used to undertake the statistical analysis.

\section{Seasonality model relating nutritive characteristics to temperature}

The data collected in the experiments were compared with a model relating cumulative temperatures to historical DMD and CP values (Schut et al. 2006a). For DMD, the model was based on data collected in WA for all annual pasture types, whereas, for CP, the model included data collected in WA from pastures dominated by broadleaf species. A total of 8 data-sets were included, combining 466 samples for DMD and 297 for CP, analysed with traditional wet chemistry at various laboratories. In this work, a generalised logistic curve (often referred to as the Richards function) was used to describe the relationship between daily mean temperatures above $4.5{ }^{\circ} \mathrm{C}$ cumulated from 21 June onwards (temperature sum). Confidence intervals $(\mathrm{P}<0.05)$ for a new observation based on the normal distribution were determined to indicate the maximum (within or between field) variation to be expected at a specific moment in time. Variation within and between paddocks due to differences in management, and pasture type were estimated by determining the maximum differences in modelled effects (REML) for experiment and pasture type at a DMD of 75 and $50 \%$ representing mid-winter and late spring, respectively.

\section{(and}

In 2006 the growing season in the agricultural region of WA was extremely short, due to the late opening rains. The season started later at Badgingarra (end of June) than Vasse (mid June) and plants senesced earlier (Figure 1). The growing season in 2007/08 was even more extreme, with some early rain falling in April at Vasse, followed by a long dry period until 14 June. By comparison, no significant rains were recorded at Avondale until 23 June (Figure 2). As a result, both seasons were very short in comparison to average years with opening rains around mid April to late April for the Southern part of SW-WA. At Vasse, winter rains in 2007 were above average and caused frequent flooding of the lower parts of the 
experimental site between July and September of 2007. Water near or above the soil surface between July and September 2007 slowed plant growth and development considerably (Figure 3).

\section{INSERT FIGURE 1 ABOUT HERE}

\section{Effects of treatments on plant nutrient concentration}

The concentration of K, P and S in plants at Vasse and Badgingarra increased as the application rate of K, P and S increased with the effects being more pronounced in winter than in spring (Table 1). Similarly, the concentration of $\mathrm{N}$ in plants at Vasse, Badgingarra and Avondale increased as the application rate of $\mathrm{N}$ increased with differences in concentration being more pronounced in spring than in winter (Table 2).

\section{INSERT TABLES 1, 2 and 3 ABOUT HERE}

The experiment at Badgingarra in 2006/07 was located on a very P deficient site and the application of $\mathrm{P}$ increased significantly $(\mathrm{P}<0.001)$ the concentrations of $\mathrm{P}$ in the first sampling/harvest (before flowering) of 2006. The concentration of P increased from 0.28 to 0.31 and $0.33 \%$ for the zero, medium and high $\mathrm{P}$ application treatments, respectively (Table 1). However, the effect of $\mathrm{P}$ application diminished later in the growing season. The concentration of $\mathrm{K}$ at the first samplings at Badgingarra differed significantly $(\mathrm{P}<0.001)$ between treatments but the levels were much higher than in the Vasse experiment (Table 1). The $\mathrm{N}$ concentrations were not significantly affected by $\mathrm{N}$ treatments (Table 2) or by the application of $\mathrm{P}$ or $\mathrm{K}$ (Table 3).

Concentrations of $\mathrm{N}, \mathrm{P}$ and $\mathrm{K}$ differed significantly $(\mathrm{P}<0.001)$ for the two pasture types, with a lower concentration for plots dominated by Brome-grass than for plots dominated by broadleaf species and Barley grass (Table 3). The significant $(\mathrm{P}<0.001)$ interaction between harvest and pasture type was due to the later onset of the decline in concentration for the plots dominated by broadleaf species than for Brome-grass plots (Figure 1).

For the experiment at Vasse in 2006/07, the concentrations of K were low and ranged from 1.64$2.15 \%$ in early August, 1.25-1.63\% in early September and 1.36-1.75\% in late September for zero, medium and high applications of $\mathrm{K}$, respectively (Table 1). The plots without $\mathrm{K}$ appeared to suffer from severe $\mathrm{K}$ deficiency, resulting in very low $\mathrm{K}$ concentrations in August. The concentrations of $\mathrm{N}$ and $\mathrm{K}$ responded significantly ( $\mathrm{P}<0.001)$ to the application of $\mathrm{N}$ and $\mathrm{K}$ respectively (Table 2 and 3). 

concentration of $\mathrm{N}$ differed significantly $(\mathrm{P}<0.001)$ between harvests and there was a significant $(\mathrm{P}<0.001)$

01 interaction between the applications of $\mathrm{S}$ and $\mathrm{N}$. High $\mathrm{S}$ supply increased $\mathrm{N}$ concentration but this was moderated when combined with medium $\mathrm{N}$ supply. For the concentration of S, only differences between harvests $(\mathrm{P}<0.001)$ and $\mathrm{S}$ supply $(\mathrm{P}<0.05)$ were significant. Both $\mathrm{S}$ treatments $(25$ and $50 \mathrm{~kg}$ of $\mathrm{S} / \mathrm{ha})$ significantly $(\mathrm{P}<0.001)$ increased the concentration of $\mathrm{S}$ at the August harvest (Table 1$)$.

For the experiments at Vasse and Avondale in 2007/08, N application significantly $(\mathrm{P}<0.001)$ affected the concentrations of $\mathrm{N}$ for the spring harvests in September and October respectively (Table 2). The high level of $\mathrm{N}$ concentration for the zero $\mathrm{N}$ treatment indicates that the soil- $\mathrm{N}$ availability was very high at Avondale. This resulted in higher levels of $\mathrm{N}$ concentration for all $\mathrm{N}$ treatments at Avondale than in the other experiments. The concentration of $\mathrm{N}$ was affected by pasture types at both sites (Table 3 ). There were significant $(\mathrm{P}<0.05)$ interactions between harvest number and pasture type, and harvest number and $\mathrm{N}$ application rate. These interactions indicate that rates of change and thus change in pattern of the relationships between pasture types and $\mathrm{N}$ application levels significantly differed over time (Table 3 and Figure 2).

\section{INSERT FIGURES 2\&3 ABOUT HERE}

\section{Effects of treatments on nutritive characteristics}

For both 2006/07 and 2007/08 experimental years, harvest number, experiment and pasture type had a significant $(\mathrm{P}<0.001)$ effect on the DMD and concentrations of NDF and ADF levels of the pastures (Table 4). There were significant $(\mathrm{P}<0.001)$ harvest by experiment (site) and harvest by pasture type interactions in 2006/07 and harvest by experiment interactions in 2007/08. Whilst the application of $\mathrm{N}$ had a significant $(\mathrm{P}<0.01)$ effect on DMD and concentration of NDF in 2007/08, the application of $\mathrm{P}$ and $\mathrm{K}$ did not have a significant effect on DMD, and concentrations of NDF and ADF for both of the experimental years. There was a significant $(\mathrm{P}<0.001)$ interaction of $\mathrm{N}$ and $\mathrm{S}$ on DMD in $2006 / 07$.

INSERT TABLE 4 ABOUT HERE 

effect and as an interaction with harvest number. This indicates that within each of the experiments, DMD and concentrations of NDF and ADF varied significantly $(\mathrm{P}<0.001)$ over the growing season for each of the pasture types (Figure 3). 

ADF and CP respectively (Table 5). Experiments were a significant term for all pasture quality variables; experiment explained an additional 1.9, 3.6, 5.0 and $8.1 \%$ of the variation in concentrations of DMD, NDF, $\mathrm{ADF}$ and $\mathrm{CP}$, respectively. In addition to seasonality and experiments, pasture type was also a significant term. However, it only explained a very small amount of the additional variation. Of the total unexplained variation, 4.6\% (DMD), 5.3\% (NDF), 6.2\% (ADF) and 23.8\% (CP) was explained by the effects of experiments, pasture type and fertilizer application. Of the fertiliser applications, only the application of $\mathrm{N}$ significantly affected CP concentrations of the pastures.

There were significant interactions between seasonality, and experiments, pasture type or $\mathrm{N}$ application for DMD and concentrations of NDF and ADF. This is highlighted in a difference in the slope of the relationships between seasonality and DMD and concentrations of NDF or ADF. The interactions only explained a very small amount of additional variation for DMD and concentrations of NDF and ADF. However, for CP the interaction between seasonality and experiment explained an additional $11.7 \%$ of the variation (Table 5). As a consequence, there were large differences in the slope of the relationships between $\mathrm{CP}$ and seasonality for the different experiments (Figure 5).

The estimated random component of variation, determined by the differences between replicates and not due to block effects, was 2.7\% DMD, 3.3\% NDF, 2.3\% ADF and 2.2\% CP. These random errors were just over half the error of the model which included seasonality only (Table 5).

\section{Predicted effects of experiment and pasture type on nutritive characteristics}

After accounting for the variation due to seasonality, the average range (the difference between the upper and lower confidence intervals for a new observation) in the values for DMD, NDF, ADF and CP over the course of a season was 18.8, 27.8, 18.4 and 15.7\%, respectively (Figure 5). The range in values can be attributed to differences within and between paddocks across experiments. The maximum differences that were modelled between experiments ranged from 2.3-6.0\% for DMD, 4.6-18.7\% for NDF and 5.8-8.6 for ADF and 1.5-17.4 for CP (Figure 6).

\section{INSERT Figure 6 ABOUT HERE}



(Figures 2 and 3). These large differences can be attributed to the lower NDF and ADF values at Vasse in 2007/08, which were due to a higher net grazing pressure, resulting from lower pasture growth due to waterlogging. The effect of experimental site on CP was large $(17.4 \%$ in winter and $1.5 \%$ in summer respectively), especially during the green phase of the season.

In addition to the effect of experimental site, pasture type had a significant yet moderate effect on DMD, ADF and CP (differences of up to 4.4, 3.9 and 5.2\%, respectively). By comparison, the effect on NDF was large (differences of up to 11.4\%). In general, the legumes had a higher DMD and CP and a lower ADF and NDF than the pasture types dominated by grasses or broadleaf species.

Differences in the nutritive characteristics between pasture types changed during the season as demonstrated by the significant pasture type and seasonality $\times$ pasture type terms in Table 5 . However, this was mainly due to a difference in the rate of change of DMD, NDF and ADF during the season. These rates of change were similar for the volunteer pasture types and the sown legumes, but Wimmera and Italian Ryegrass had a higher rate of change from winter to summer.

\section{Discussion and conclusions}

Seasonality, as described by the cumulative temperature, explained $82,79,79$, and $62 \%$ of the variation in DMD and concentrations of NDF, ADF and CP respectively. Differences due to site characteristics and grazing management were significant but small and explained additional variation on top of seasonality for all of the nutritive characteristics, (1.9, 3.6, 5.0 and 8.1\% for DMD, NDF, ADF and CP respectively).

The relationship provides a simple means to describe the DMD and concentrations of NDF and ADF of an average pasture in Mediterranean climates of Australia. The DMD values from the four experiments fitted well within the confidence intervals of historical data and spanned the full range (Schut $e t$ al. 2006a). It demonstrates that the most important sources of variation were covered in our experiments, and that these confidence intervals can be used to identify the amount of spatial variation to be expected, providing values for high and low quality pastures. The differences between the extremes, i.e. very good and poor pastures, that can be expected at any time in the growing season is $18.8,27.8,18.4$ and $15.7 \%$ for DMD and concentrations of NDF, ADF and CP respectively. About half of this spatial variability can be attributed to unexplained (random) variation, the other half can be explained by differences between pasture species, 
site characteristics, nitrogen application rate (for CP only) and other management factors (such as grazing regime).

Detailed knowledge about the botanical composition of pastures and grazing management can be used to approximate nutritive characteristics (Moore et al. 1997). Estimates of the average pasture and the spatial variation in nutritive characteristics can be used to quantify qualitative assessments of high and low quality pastures. That is, for paddocks with a high net grazing pressure, such as in Vasse in 2007/08, the DMD can be expected to be 0 to $5 \%$ above average from winter through to summer, for paddocks with a predominance of legumes the DMD can be expected to be 3 (subterranean clover) to 6\% (Serradella) above the average throughout the growing season. However, concentrations of NDF and ADF were strongly affected by site and intensive grazing and this approach may only be applied at low to moderate grazing intensity.

The animal's feed intake and ability to select will depend on the availability of pools of forage with different nutritive characteristics. The availability of these pools is approximated from the height and feedon-offer or is modelled deterministically in decision support tools for grazing management such as GrazFeed or GrassGro (Freer 2002; Moore et al. 1997). Alternatively, the relative abundance of these pools of forage may also be directly derived from or constrained by the expected DMD of the feed-on-offer at a particular cumulative temperature. For poor, average or good quality pastures, the DMD value is expected within a fairly narrow range of values, constraining the possible abundances of the pools of forage present.

Although lowest concentrations of $\mathrm{P}$ and $\mathrm{K}$ observed indicated severe deficiencies (Pinkerton et al. 1997), the application of $\mathrm{P}$ and K fertilizer did not have an effect on DMD and concentrations of NDF, ADF or CP. By comparison, Cayley et al. (2002) found an increase in DMD for green clover and CP for perennial ryegrass, green clover and subterranean clover with increasing application of $\mathrm{P}$ and $\mathrm{N}$. Levels of $\mathrm{CP}$ varied markedly between our experiments and strongly responded to $\mathrm{N}$ application (Schut et al. 2006a). After combining all experimental data, the effects of $\mathrm{N}$ application on DMD and concentrations of NDF and ADF were not significant after accounting for the effects of seasonality, pasture type and site, confirming findings of Elliot and Abbott (2003). Under high N supply, S deficiency can limit the growth and protein content of grassland (Gierus et al. 2005). However, at Vasse in 2006/07, this was not the case as the concentrations of S were well above critical values. There was also a significant $N \times S$ interaction which is inexplicable.

Legumes have a higher DMD and protein concentration than grasses or broadleaf species (McIvor et al. 1973), but also a lower fibre content. Rossiter et al. (1985) found no major differences between Serradella 
and subterranean clover, but in our study Serradella had a higher DMD and a lower concentration of NDF and ADF throughout the growing season. No major differences were found between Italian and Wimmera ryegrass in DMD or concentrations of NDF and ADF.

The NDF and ADF values were strongly correlated with DMD but relationships differed between experiments, resulting in a shift in the level of NDF and ADF at a given DMD value. This was mainly due to a much stronger effect of site and management on NDF and ADF than on DMD. In the summer period of the 2006/07 season, DMD values slightly increased, NDF was more or less constant but ADF levels slightly decreased. This was unexpected, and may be due to the effect of summer rainfall in January 2007.

In conclusion, the sum of daily mean temperatures above $4.5^{\circ} \mathrm{C}$ can be used to describe changes and estimate nutritive characteristics of an average pasture and the expected spatial variability in DMD, and concentrations of NDF and ADF in the dry matter over a growing season. This can then be used to compare and benchmark growing seasons and experiments in various years, providing a means to better understand and predict animal performance across years, to quantify expert assessments of pasture quality and to quantify differences within and between paddocks in an area measured with remote sensing (Schut et al. 2006b; Vickery et al. 1997). 
436 Callow MN, Michell P, Baker JE, Hough GM (2000) The effect of defoliation practice in Western Australia on tiller development of annual ryegrass (Lolium rigidum) and Italian ryegrass (Lolium multiflorum) and its association with forage quality. Grass and Forage Science 55, 232-241.

Cayley JWD, Saul GR, McCaskill MR (2002) High-fertility pastures in south-west Victoria can be economically and environmentally sustainable. Wool Technology and Sheep Breeding 50, 724-729.

Coleman SW, Henry DA (2002) Nutritive value of Herbage. In 'Sheep Nutrition'. (Eds M Freer, H Dove) pp.

Melbourne).

Elliott DE, Abbott RJ (2003) Nitrogen fertiliser use on rain-fed pasture in the Mt Lofty Ranges, South

Australia. 1. Pasture mass, composition and nutritive characteristics. Australian Journal of Experimental Agriculture 43, 553-577.

Freer M (2002) The nutritional management of grazing sheep. In 'Sheep Nutrition'. (Eds M Freer, H Dove) pp. 357-373. (CSIRO Publishing: Collingwood, Australia).

Gierus M, Jahns U, Wulfes R, Wiermann C, Taube F (2005) Forage quality and yield increments of intensive managed grassland in response to combined sulphur-nitrogen fertilization. Acta Agriculturae Scandinavica Section B-Soil and Plant Science 55, 264-274.

460 529-545 
Henry DA, Simpson RJ, Macmillan RH (2000) Seasonal changes and the effect of temperature and leaf moisture content on intrinsic shear strength of leaves of pasture grasses. Australian Journal of Agricultural Research 51, 823-831.

Justes E, Mary B, Meynard JM, Machet JM, Thelier Huche L (1994) Determination of a critical nitrogen dilution curve for winter wheat crops. Annals of Botany 74, 397-407.

Lemaire G, Gastal F, Salette J (1989) Analysis of the effect of N nutrition on dry matter yield of a sward by reference to potential yield and optimum N content. In 'The XVI International Grassland Congress'. Nice, France pp. 179-180.

McIvor JG, Smith DF (1973) Plant factors influencing the nutritive value of some temperate pasture species. Australian Journal of Experimental Agriculture 13, 404-410.

Moore AD, Donnelly JR, Freer M (1997) GRAZPLAN: Decision support systems for Australian grazing enterprises .3. Pasture growth and soil moisture submodels, and the GrassGro DSS. Agricultural Systems 55, 535-582.

Payne RW, Welham SJ, Harding SH (2007) 'A Guide to REML in GenStat.' (VSN International: Hertfordshire, UK.).

Pinkerton A, Smith FW, Lewis DC (1997) Pasture species. In 'Plant analysis. An interpretation manual'. (Eds DJ Reuter, JB Robinson). (CSIRO: Collingwood, Victoria).

Rossiter RC, Collins WJ, Klein L (1985) Winter growth and nutritive quality of Serradella (Ornithopus Spp). Australian Journal of Experimental Agriculture 25, 362-366.

Ru YJ, Fortune JA (2000) Variation in nutritive value of plant parts of subterranean clover (Trifolium subterraneum L.). Australian Journal of Experimental Agriculture 40, 397-403. 
Ru YJ, Fortune JA (2001) Seed yield and nutritive value of dry, mature subterranean clover (Trifolium subterraneum L.). Australian Journal of Experimental Agriculture 41, 169-175.

497

Schut AGT, Thompson AN, Gherardi SG, Metternicht G (2006a) Seasonal changes in pasture quality in

Mediterranean regions of Australia. In 'Ground-breaking stuff. Proceedings of the 13th Australian Agronomy

500

Conference, 10-14 September 2006. Australian Society of Agronomy'. Perth, Western Australia. (Eds NC

501

Turner, T Acuna, RC Johnson). (The Regional Institute Ltd.

502

http://www.regional.org.au/au/asa/2006/poster/technology/4665_schutagt.htm).

503

504

Schut AGT, van der Heijden GWAM, Hoving I, Stienezen MWJ, Van Evert FK, Meuleman J (2006b)

505

Imaging spectroscopy for on-farm measurement of grassland yield and quality. Agronomy Journal 98, 1318-

506 1325.

507

508

Vickery PJ, Hill MJ, Donald GE (1997) Satellite derived maps of pasture growth status: Association of 509 classification with botanical composition. Australian Journal of Experimental Agriculture 37, 547-562. 
Figure 1. Temporal changes in pasture yield (green and dead feed-on-offer, gFOO and dFOO) and concentrations of dry matter content (DMc), in-vitro digestibility (DMD), neutral detergent fiber (NDF), acid detergent fiber (ADF), nitrogen (N), phosphorus (P) and potassium (K) for Badgingarra (BRS06) and Vasse (VRS06) in 2006 (BG: Brome grass, BL broadleaf dominated plots, VG Barley and Ryegrass dominated plots).

519

Figure 2. Temporal changes in pasture yield (green and dead feed-on-offer, gFOO and dFOO) and concentrations of dry matter content (DMc), in-vitro digestibility (DMD), neutral detergent fiber (NDF), acid detergent fiber (ADF), nitrogen (N), phosphorus (P) and potassium (K) for Avondale in 2007. Pasture types include volunteer annual grasses (VG), broadleaves (BL) and the sown pasture species Wimmera ryegrass (WR), Italian ryegrass (IR), subterranean clover (SC), Biserrula (BI) and Serradella (SD). include broadleaf species (BL), sown Wimmera ryegrass (WR) and Italian ryegrass (IR). $\mathrm{RMSE}=4.4)$ and $\mathrm{ADF}=65.6-0.55 \times \mathrm{DMD}\left(\mathrm{R}^{2}=0.93, \mathrm{RMSE}=2.0\right)$.

Figure 5. Experimental data compared with seasonality model relating cumulative temperature to historical in-vitro dry-matter digestibility (DMD) and crude protein (CP) values. Upper and lower lines indicate 95\% confidence intervals for a new observation as determined by historical data from Western Australia. 
543 Figure 6. Estimated effects of experiment and pasture type in addition to seasonality for in-vitro dry matter 544 digestibility (DMD), neutral detergent fiber (NDF), acid detergent fiber (ADF) and crude protein (CP) for 545 experiments conducted at Avondale (ARS), Badgingarra (BRS), and Vasse (VRS, in 2006 and 2007). The 546 pasture types include volunteer annual grasses (VG), broadleaf species (BL), Brome grass (BG) and the sown 547 species Wimmera ryegrass (WR), Italian ryegrass (IR), subterranean clover (SC), Biserrula (BI) and 548 Serradella (SD) in winter and summer. Based on REML estimates of site and pasture type effects, 549 comparisons between sites were calculated for broadleaves, and comparisons between pasture types for 550 Avondale including all significant terms as listed in Table 5. 

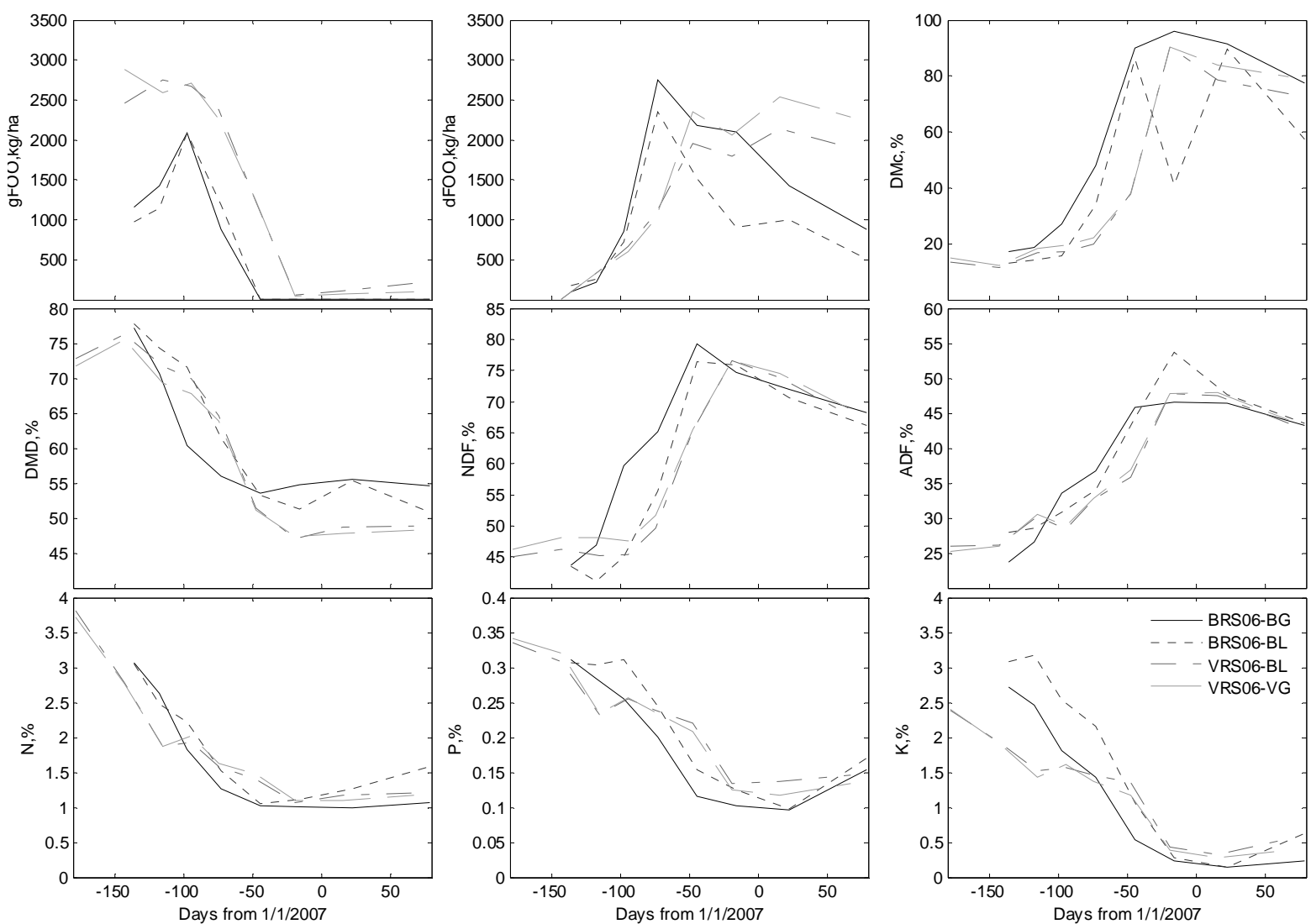

Figure 1. 

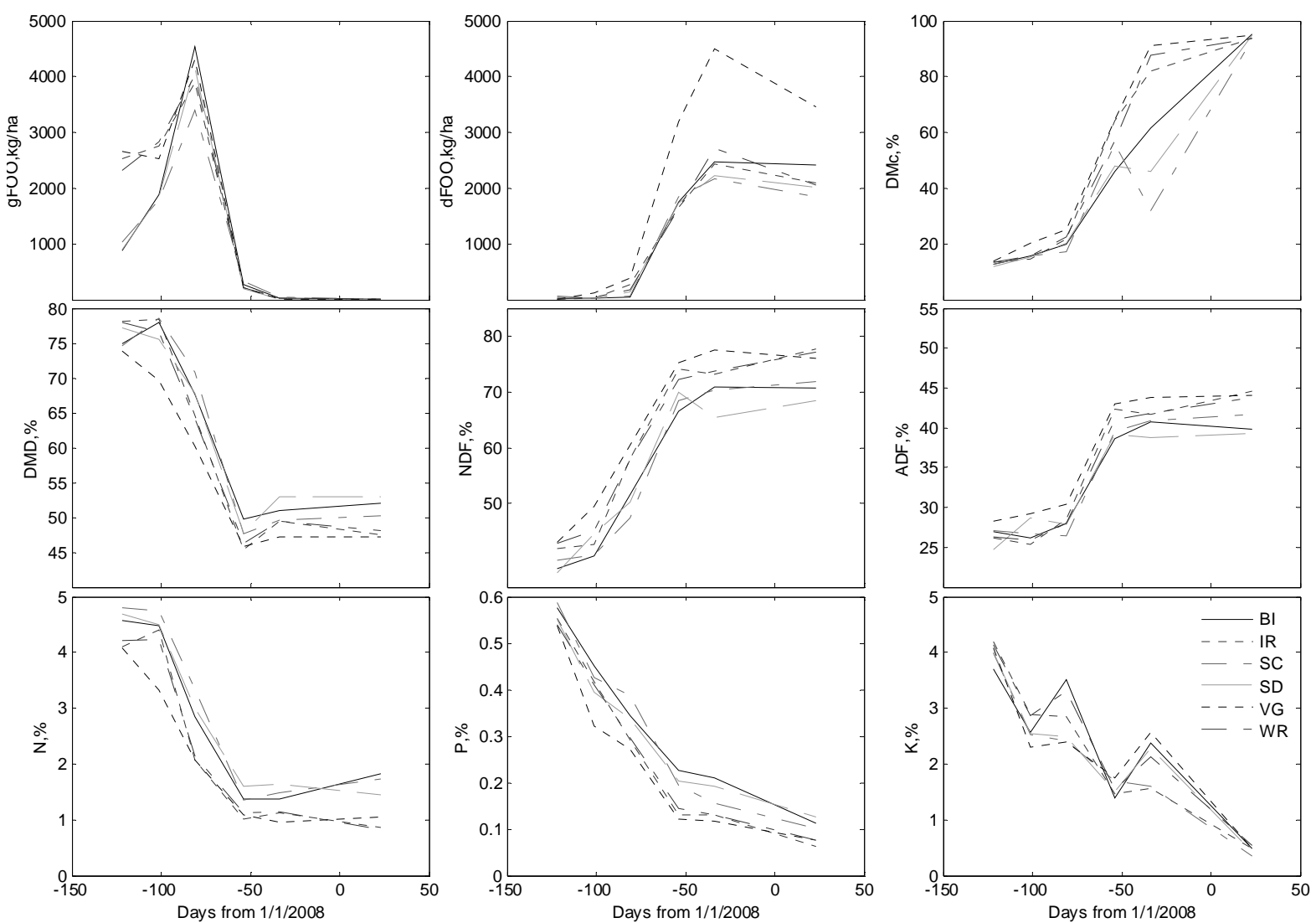

Figure 2. 

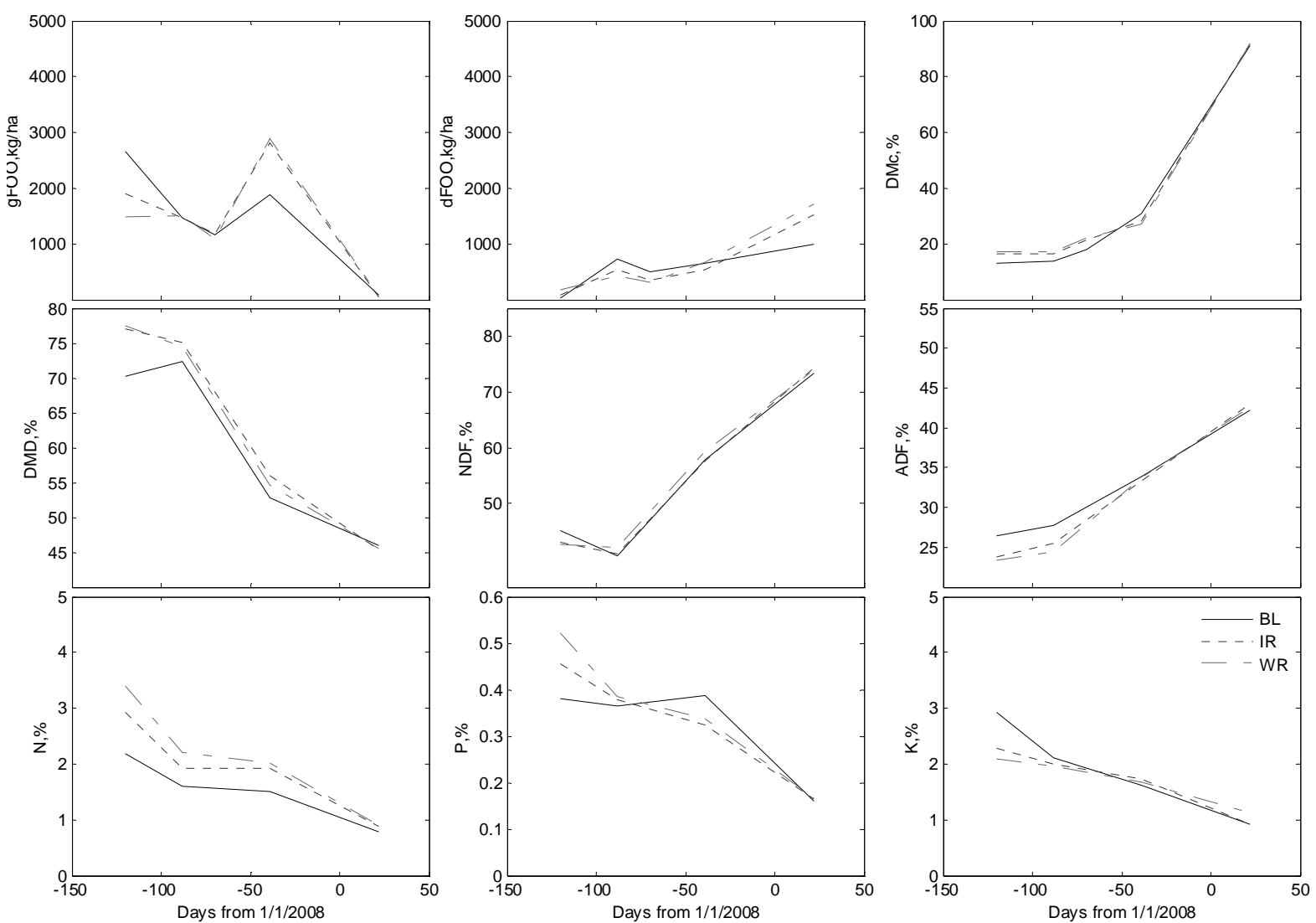

Figure 3. 

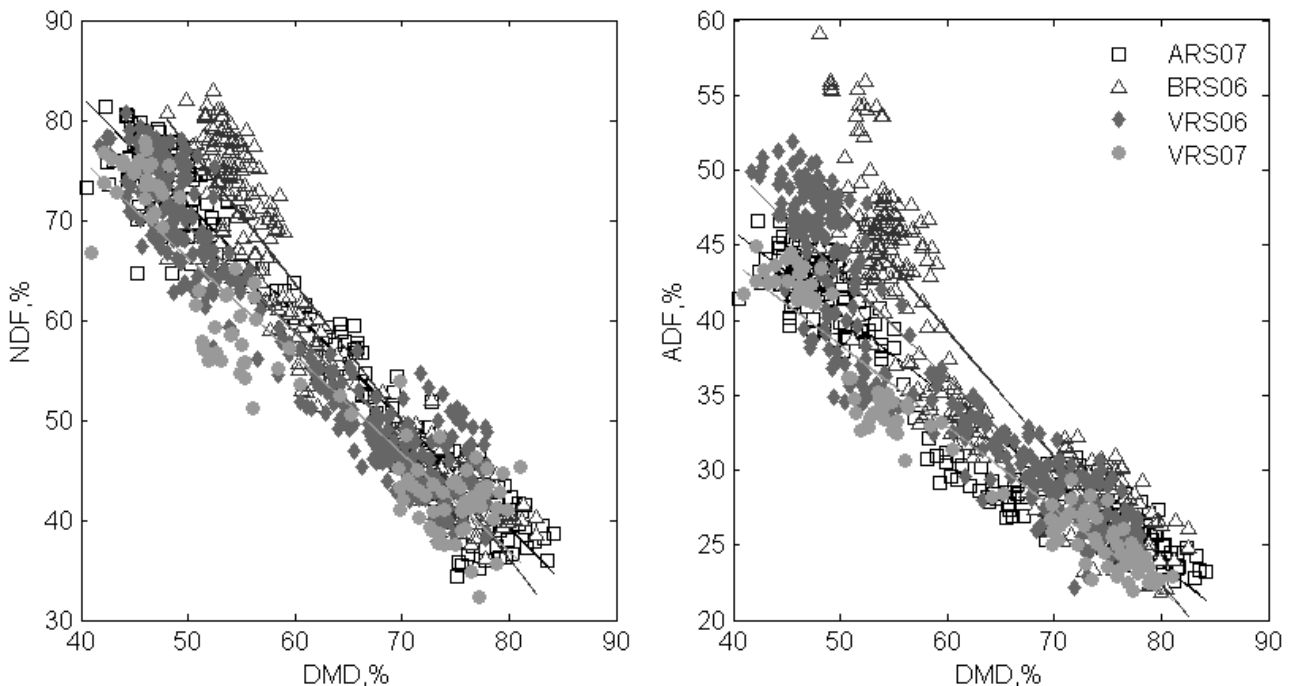

$565 \quad$ Figure 4 

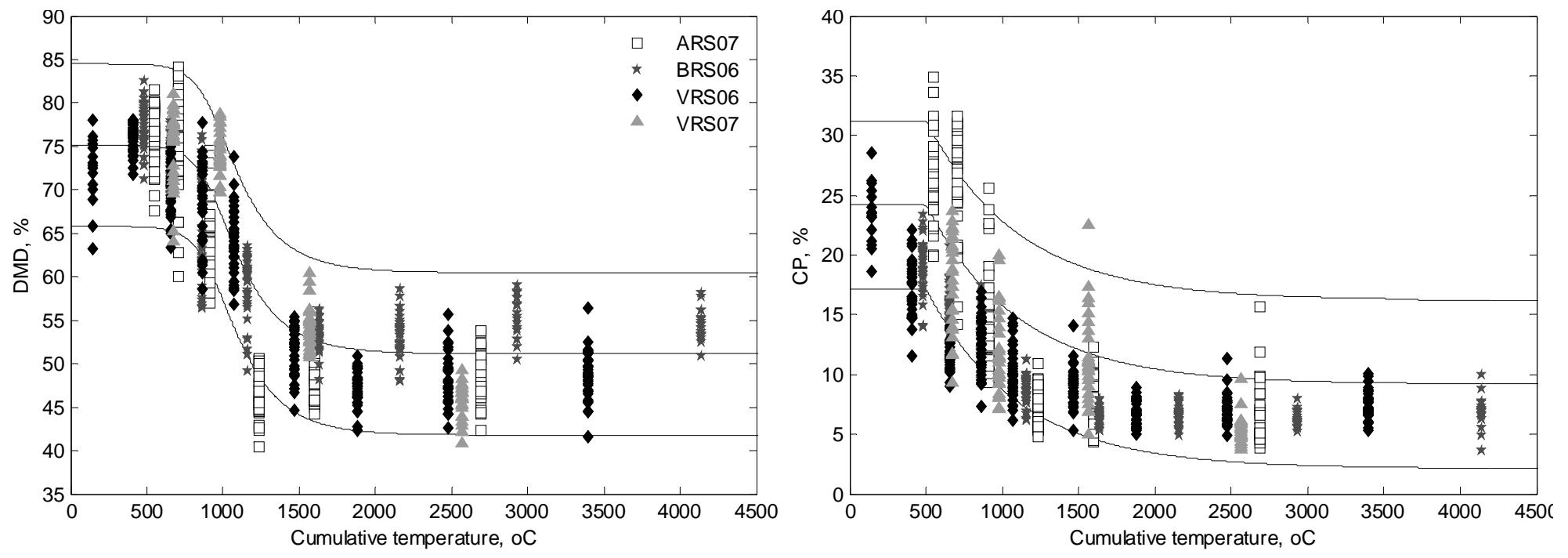

Figure 5. 

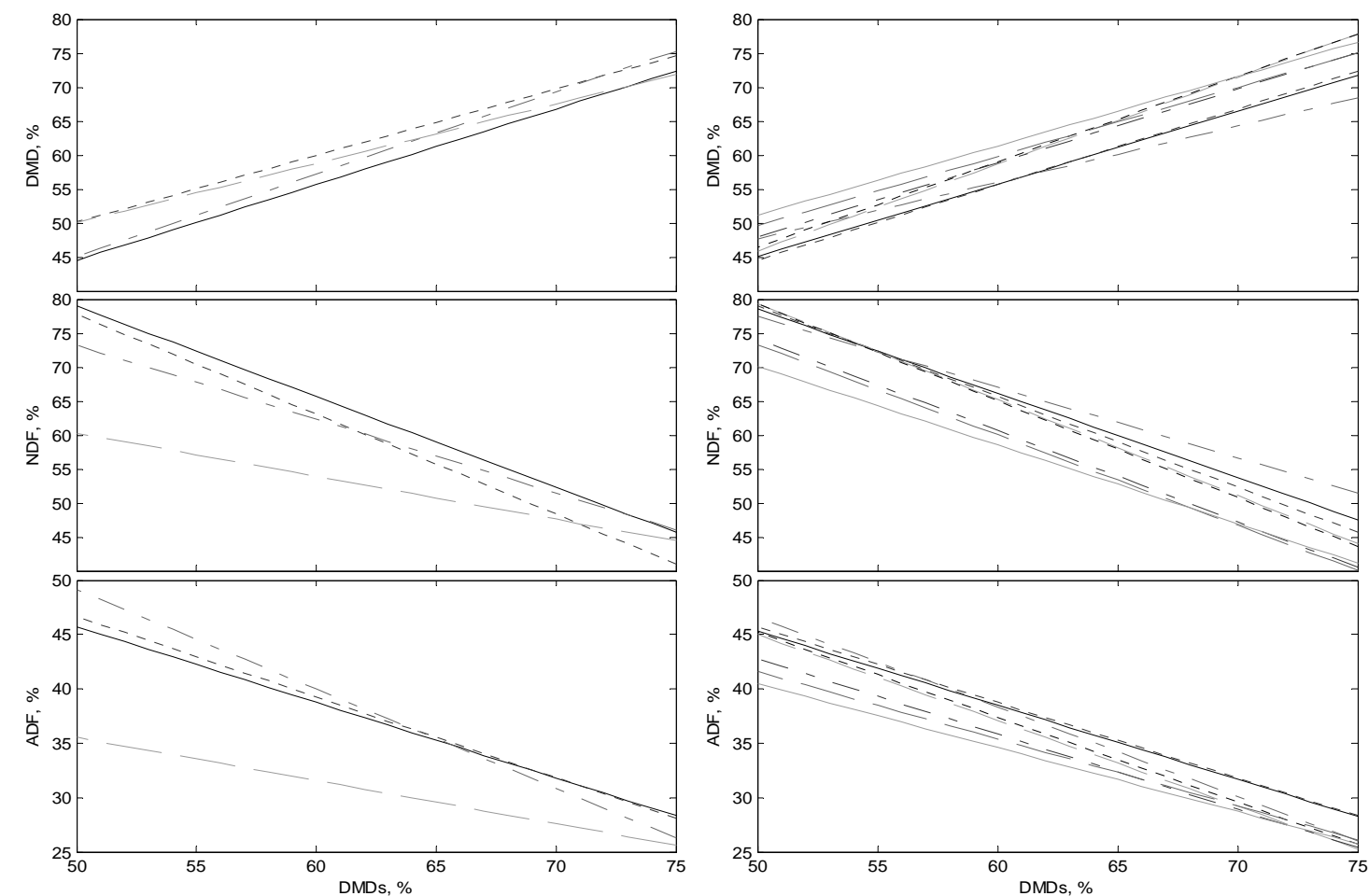

571
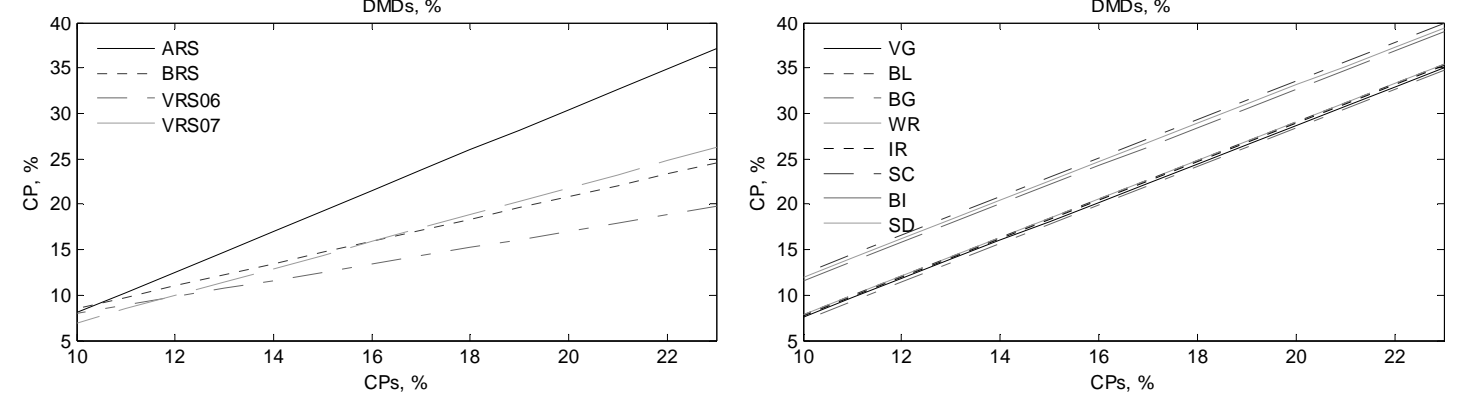

Figure 6. 
579 different application levels of $\mathrm{K}$ and $\mathrm{S}$ or $\mathrm{P}$ fertilizer. $\mathrm{P}$ values indicate significance of main effects in analysis of variance.
$K, \quad S$ or $P$
Vasse, 2006
Badgingarra, 2006

supply

\begin{tabular}{|c|c|c|c|c|}
\hline & 10 Aug & 28 Sep & 17 Aug & 25 Sep \\
\hline None & 1.64 & 1.36 & 2.80 & 2.13 \\
\hline Medium & 1.97 & 1.67 & 2.88 & 2.21 \\
\hline High & 2.15 & 1.75 & 3.06 & 2.24 \\
\hline \multirow[t]{2}{*}{ P value } & $<0.05$ & NS & $<0.001$ & NS \\
\hline & \multicolumn{2}{|c|}{ 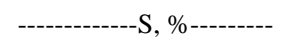 } & \multicolumn{2}{|c|}{ 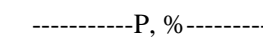 } \\
\hline None & 0.27 & 0.17 & 0.28 & 0.17 \\
\hline Medium & 0.29 & 0.17 & 0.31 & 0.18 \\
\hline High & 0.30 & 0.18 & 0.33 & 0.18 \\
\hline P value & $<0.001$ & NS & $<0.001$ & $<0.05$ \\
\hline
\end{tabular}


583 significance of main effects in an analysis of variance.

\begin{tabular}{|c|c|c|c|c|c|c|c|c|c|c|c|c|}
\hline \multirow[t]{2}{*}{$N$ supply } & \multicolumn{3}{|c|}{ Vasse, 2006} & \multicolumn{3}{|c|}{ Badgingarra, 2006} & \multicolumn{3}{|c|}{ Avondale, 2007} & \multicolumn{3}{|c|}{ Vasse, 2007} \\
\hline & $\mathrm{N}, \mathrm{kg} / \mathrm{ha} / \mathrm{yr}$ & 10 Aug & 28 Sep & $\mathrm{N}, \mathrm{kg} / \mathrm{ha} / \mathrm{yr}$ & 17 Aug & 25 Sep & $\mathrm{N}, \mathrm{kg} / \mathrm{ha} / \mathrm{yr}$ & 31 Aug & 21 Sep & $\mathrm{N}, \mathrm{kg} / \mathrm{ha} / \mathrm{yr}$ & 2 Sep & $4 \mathrm{Oct}$ \\
\hline None & 0 & 2.49 & 1.60 & 0 & 2.93 & 1.94 & 0 & 4.42 & 4.10 & 0 & 2.70 & 1.58 \\
\hline Low & 45 & 2.65 & 2.05 & 20 & 2.94 & 2.00 & 35 & 4.03 & 3.95 & 35 & 2.87 & 1.94 \\
\hline Medium & 90 & 2.82 & 2.17 & 40 & 3.26 & 2.08 & 70 & 4.22 & 4.38 & 70 & 2.97 & 2.18 \\
\hline High & 135 & 3.15 & 2.14 & 60 & 3.10 & 2.10 & & & & & & \\
\hline$P$ value & & $<0.001$ & 0.001 & & NS & NS & & NS & $<0.01$ & & NS & $<0.05$ \\
\hline
\end{tabular}



interactions as potential model terms. Only significant terms $(\mathrm{F}$ test, $\mathrm{P}<0.05)$ were included in the final model.

\begin{tabular}{|c|c|c|c|c|c|c|c|c|c|c|}
\hline $\begin{array}{c}\text { Experiments } \\
\text { Included }\end{array}$ & \multirow[t]{2}{*}{ Treatments } & \multirow[t]{2}{*}{ Model } & \multirow[t]{2}{*}{$N$} & \multicolumn{7}{|c|}{ F probabilities for model terms } \\
\hline & & & & $\mathrm{H}$ & $\mathrm{T}$ & $\mathrm{N}$ & $\mathrm{P}, \mathrm{K}$ or $\mathrm{S}$ & $\mathrm{H} \times \mathrm{T}$ & $\mathrm{H} \times \mathrm{N}, \mathrm{H} \times \mathrm{K}, \mathrm{H} \times \mathrm{P}$ or $\mathrm{H} \times \mathrm{S}$ & $\mathrm{N} \times \mathrm{S}$ \\
\hline \multirow[t]{3}{*}{ Badgingarra, 2006} & N, P, K application & $\mathrm{Nc}=\mathrm{a}+\mathrm{H}+\mathrm{T}+\mathrm{N}+\mathrm{H} \times \mathrm{T}$ & 252 & $<0.001$ & $<0.001$ & 0.208 & & $<0.001$ & & \\
\hline & & $\mathrm{Pc}=\mathrm{a}+\mathrm{H}+\mathrm{T}+\mathrm{P}+\mathrm{H} \times \mathrm{T}+\mathrm{H} \times \mathrm{P}$ & 252 & $<0.001$ & $<0.001$ & & $<0.001$ & $<0.001$ & 0.005 & \\
\hline & & $\mathrm{Kc}=\mathrm{A}+\mathrm{H}+\mathrm{T}+\mathrm{K}+\mathrm{H} \times \mathrm{T}$ & 252 & $<0.001$ & $<0.001$ & & 0.012 & $<0.001$ & & \\
\hline \multirow[t]{3}{*}{ Vasse, 2006} & N, S, K application & $\mathrm{Nc}=\mathrm{a}+\mathrm{H}+\mathrm{N}+\mathrm{S}+\mathrm{H} \times \mathrm{N}+\mathrm{N} \times \mathrm{S}$ & 273 & $<0.001$ & & $<0.001$ & 0.156 & & 0.002 & $<0.001$ \\
\hline & & $\mathrm{Kc}=\mathrm{A}+\mathrm{H}+\mathrm{K}+\mathrm{H} \times \mathrm{K}$ & 273 & $<0.001$ & & & $<0.001$ & & 0.029 & \\
\hline & & $\mathrm{Sc}=\mathrm{a}+\mathrm{H}+\mathrm{S}$ & 273 & $<0.001$ & & & 0.024 & & & \\
\hline \multirow[t]{2}{*}{ Avondale, 2007} & Pasture type, & $\mathrm{Nc}=\mathrm{a}+\mathrm{H}+\mathrm{T}+\mathrm{N}+\mathrm{H} \times \mathrm{T}+\mathrm{H} \times \mathrm{N}$ & 216 & $<0.001$ & $<0.001$ & 0.021 & & $<0.001$ & 0.040 & \\
\hline & $\mathrm{N}$ application & & & & & & & & & \\
\hline \multirow[t]{2}{*}{ Vasse, 2007} & Pasture type, & $\mathrm{Nc}=\mathrm{a}+\mathrm{H}+\mathrm{T}+\mathrm{N}+\mathrm{H} \times \mathrm{T}+\mathrm{H} \times \mathrm{N}$ & 135 & $<0.001$ & $<0.001$ & 0.976 & & $<0.001$ & 0.026 & \\
\hline & $\mathrm{N}$ application & & & & & & & & & \\
\hline
\end{tabular}


591 potassium (K)) on the nutritive characteristics of pastures. Final REML model and F probabilities for in-vitro dry matter digestibility (DMD), neutral detergent fiber

592 (NDF) and acid detergent fiber (ADF) in 2006/07 and 2007/08 seasons.

\begin{tabular}{|c|c|c|c|c|c|c|c|c|c|}
\hline \multirow[t]{2}{*}{ Model } & \multirow[t]{2}{*}{ Number of samples } & \multicolumn{8}{|c|}{ F probabilities for model terms } \\
\hline & & $\mathbf{H}$ & $\mathbf{E}$ & $\mathbf{T}$ & $\mathbf{H} \times \mathbf{E}$ & $\mathbf{H} \times \mathbf{T}$ & $\mathbf{N}$ & $\mathbf{S}$ & $\mathbf{N} \times \mathbf{S}$ \\
\hline \multicolumn{10}{|l|}{ 2006/07 } \\
\hline $\mathrm{DMD}=\mathrm{a}+\mathrm{H}+\quad \mathrm{T}+\mathrm{H} \times \mathrm{E}+\mathrm{H} \times \mathrm{T}+\mathrm{N}+\mathrm{S}+\mathrm{N} \times \mathrm{S}$ & 525 & $<0.001$ & $<0.001$ & $<0.001$ & $<0.001$ & $<0.001$ & 0.224 & 0.983 & $<0.001$ \\
\hline $\mathrm{NDF}=\mathrm{a}+\mathrm{H}+\mathrm{E}+\mathrm{T}+\mathrm{H} \times \mathrm{E}+\mathrm{H} \times \mathrm{T}+\mathrm{N}+\mathrm{S}+\mathrm{N} \times \mathrm{S}$ & 525 & $<0.001$ & $<0.001$ & $<0.001$ & $<0.001$ & $<0.001$ & - & - & - \\
\hline$A D F=a+H+E+T+H \times E+H \times T$ & 525 & $<0.001$ & $<0.001$ & $<0.001$ & $<0.001$ & $<0.001$ & - & - & - \\
\hline 2007/08 & & $\mathbf{H}$ & $\mathbf{E}$ & $\mathbf{T}$ & $\mathbf{N}$ & $\mathbf{H} \times \mathbf{E}$ & $\mathbf{H} \times \mathbf{T}$ & $\mathbf{H} \times \mathbf{N}$ & $\mathbf{N} \times \mathbf{T}$ \\
\hline $\mathrm{DMD}=\mathrm{a}+\mathrm{H}+\mathrm{E}+\mathrm{T}+\mathrm{H} \times \mathrm{E}$ & 310 & $<0.001$ & $<0.001$ & $<0.001$ & - & $<0.001$ & - & - & - \\
\hline $\mathrm{NDF}=\mathrm{a}+\mathrm{H}+\mathrm{E}+\mathrm{T}+\mathrm{N}+\mathrm{H} \times \mathrm{E}$ & 310 & $<0.001$ & $<0.001$ & $<0.001$ & 0.002 & $<0.001$ & - & - & $<0.001$ \\
\hline $\mathrm{ADF}=\mathrm{a}+\mathrm{H}+\mathrm{E}+\mathrm{T}+\mathrm{H} \times \mathrm{E}$ & 310 & $<0.001$ & $<0.001$ & $<0.001$ & - & $<0.001$ & - & - & \\
\hline
\end{tabular}



test) of variation to describe in-vitro dry matter digestibility (DMD), neutral detergent fiber (NDF), acid detergent fiber (ADF) and crude protein (CP) with fitted REML models. Components of variation included were seasonality (Se, temporal variation determined by estimates of CPs and DMDs), experiment (E), pasture type (T), nitrogen application rate $(\mathrm{N})$ and their interactions. The random component of the RMSE describes the residual error which originates from differences between replicates after and Vasse).

\begin{tabular}{|c|c|c|c|c|c|c|c|c|c|}
\hline \multirow{3}{*}{$\begin{array}{l}\text { Variation type } \\
\text { Model component } \\
\text { Terms }\end{array}$} & \multirow{3}{*}{$\begin{array}{c}\text { Temporal } \\
\text { Fixed } \\
\text { Se }\end{array}$} & \multicolumn{7}{|c|}{ Within or between field } & \multirow{3}{*}{$\begin{array}{c}\text { Random } \\
\text { Residual }\end{array}$} \\
\hline & & \multicolumn{7}{|c|}{ Fixed } & \\
\hline & & $\mathrm{E}$ & $\mathrm{T}$ & $\mathrm{N}$ & Se×E & $\mathrm{Se} \times \mathrm{T}$ & $\mathrm{Se} \times \mathrm{N}$ & $\mathrm{E} \times \mathrm{T}$ & \\
\hline DMD & 82.0 & 83.9 & 84.8 & NS & 86.6 & 87.5 & NS & NS & \\
\hline NDF & 79.0 & 82.6 & 84.0 & NS & 84.3 & 84.9 & NS & NS & \\
\hline $\mathrm{ADF}$ & 79.2 & 84.2 & 84.8 & NS & 85.1 & 85.4 & NS & NS & \\
\hline $\mathrm{CP}$ & 61.8 & 69.9 & 72.5 & 73.4 & 85.1 & 85.3 & 85.6 & NS & \\
\hline DMD, \% & 5.0 & 4.7 & 4.6 & NS & 4.3 & 4.14 & NS & NS & 2.7 \\
\hline NDF, \% & 6.4 & 5.8 & 5.6 & NS & 5.5 & 5.4 & NS & NS & 3.3 \\
\hline ADF, \% & 3.9 & 3.4 & 3.4 & NS & 3.3 & 3.3 & NS & NS & 2.3 \\
\hline СР, \% & 4.0 & 3.6 & 3.4 & 3.3 & 2.5 & 2.5 & 2.5 & NS & 2.2 \\
\hline
\end{tabular}

